\title{
Nest structure and colony cycle of the Allegheny mound ant, Formica exsectoides Forel (Hymenoptera: Formicidae)
}

\author{
C. M. Bristow ${ }^{1}$, D. Cappaert ${ }^{2}$, N. J. Campbell ${ }^{1, *}$ and A. Heise ${ }^{3}$ \\ 1 Dept. of Entomology, Michigan State University, East Lansing, MI 48824 \\ 2 Dept. of Biology, University of Michigan, Ann Arbor, MI 48109. Current address: 1726 Dexter, Ann \\ Arbor, $M I$ 48103, USA \\ 3 Dept. of Biology, University of Michigan, Ann Arbor, MI 48109 \\ * Current address: USDA-Forest Service, PO Box 7669, Missoula, MT 59807
}

Key words: Formica exsectoides, nests, colony cycle, temperature, brood, reproductives.

\section{Summary}

The nest structure and colony cycle of a population of Allegheny mound ants, Formica exsectoides, were examined in central Michigan. The dispersion pattern of mounds was random. Nest structure and presence of brood were primarily determined by excavation of twenty-three nests over three intervals from June through September. Additional excavations of five nests in 1990 and ten nests in 1991 provided further details on nest structure and colony cycle. Most galleries occurred within the mound and upper $30 \mathrm{~cm}$ of soil, but some activity reached depths of 100 to $270 \mathrm{~cm}$. Depth of nests showed little correlation with external measurements of height and diameter. Immature stages were recovered from two strata: the upper $20 \mathrm{~cm}$ of nest and mound and the lowest nest depths. Alate sexual forms were found in or near the mound in July, and numerous dealate queens were collected in September from peripheral galleries near the soil surface.

\section{Introduction}

The Allegheny mound ant, Formica exsectoides Forel, is a common mound-building ant in North America (Wheeler, 1910), frequently forming dense local populations throughout the northeastern and central portions of the United States and southern Canada (Creighton, 1950). In areas where populations have become established, the large thatched mounds form a conspicuous feature of the landscape. McCook (1877) counted 1700 mounds in a 50 acre area near Hollidaysburg, Pa, and Andrews (1925a, b) and Cory and Haviland (1938) described similar populations in Maryland.

Despite the abundance and wide geographic range of $F$. exsectoides, previous field studies have treated only limited details of its life history and biology. McCook (1877), Andrews (1925a, 1926, 1927, 1929a, b) and Cory and Haviland (1938) focused on aspects of mound size, growth and function. Salem and Hole (1968) described the ants' effect on the soil profile. Peirson $(1922,1923)$ and Andrews (1928) 
discussed the potential pest status of Allegheny mound ants, while Dimmick (1951) recorded the ants' response to temperaure and humidity. More recently, Nipson (1978) addressed the degree of inbreeding in this species. The beneficial effect of the ants as biological control agents of forest pests has also been examined (Campbell, 1990; Campbell et al. 1991). Most of the studies of the basic ecology of the ants were conducted in the central portions of its range. In this paper, we report additional details of colony cycle and seasonal patterns of nest use for populations in midMichigan, near the northwestern edge of the species' geographic range. The results of this study not only provide additional details on the ecology and behavior of this important group, but enhance our base of comparison with the better studied European mound-building ants of the $F$. rufa group.

\section{Materials and methods}

\section{Study site}

The study was conducted in the spring and summer of 1989 through 1991, in Crawford County, Michigan. The primary study sites were in the Huron-Manistee National Forest, approximately $8 \mathrm{~km}$ east of Roscommon. The sites were all located on gently rolling Grayling sand soils. These are part of the Grayling-Rubicon soil association, which covers an area of over 373000 hectares in northern lower Michigan (MacDonald, 1983). The Grayling sand soils that compose the field sites are classified as mixed frigid Typic Udipsamments (USDA, 1976), and are characterized as excessively drained sandy nutrient-poor soils that support an edaphic climax community dominated by jack pine (Pinus banksiana L.). The area in Crawford County receives moderate precipitation, with an annual average of $84.3 \mathrm{~cm}$ distributed throughout the year (Strommen, 1971).

The predominant vegetation in the area is open canopy jack pine with an understory of oak saplings (probably black oak), Quercus sp. Ground cover is primarily lichen, lowbush blueberry (Vaccinium angustifolium) and sweet fern (Comptonia peregrina), with mixed grasses in the more open areas. Jack pine forests in this area are maintained by wildfires or controlled burns. The area contains numerous well-established populations of the Allegheny mound ant. During the course of the study, ant mounds were sampled from three sites in the Hunter Lake area of Crawford County. Site 1 provided the 23 mounds excavated in 1989. Site 2, located approximately $3 \mathrm{~km}$ southeast of Site 1, was mapped for nest dispersion in 1990 , and an additional ten nests were fully or partially excavated over the next two years to assess presence and activity of different life stages. Five additional mounds were excavated in 1990 and 1991 at a third site approximately $1.5 \mathrm{~km}$ west of site 2 . Vegetation, soil and ant density were similar at all three sites. Table 1 presents a summary of the locations and dates of excavations in seasonal order.

\section{Determination of nest structure and stage presence and location}

Twenty-four mounds were selected at Site 1 on May 27, 1989 from approximately 100 active mounds, and were randomly assigned to one of three sample groups to be 


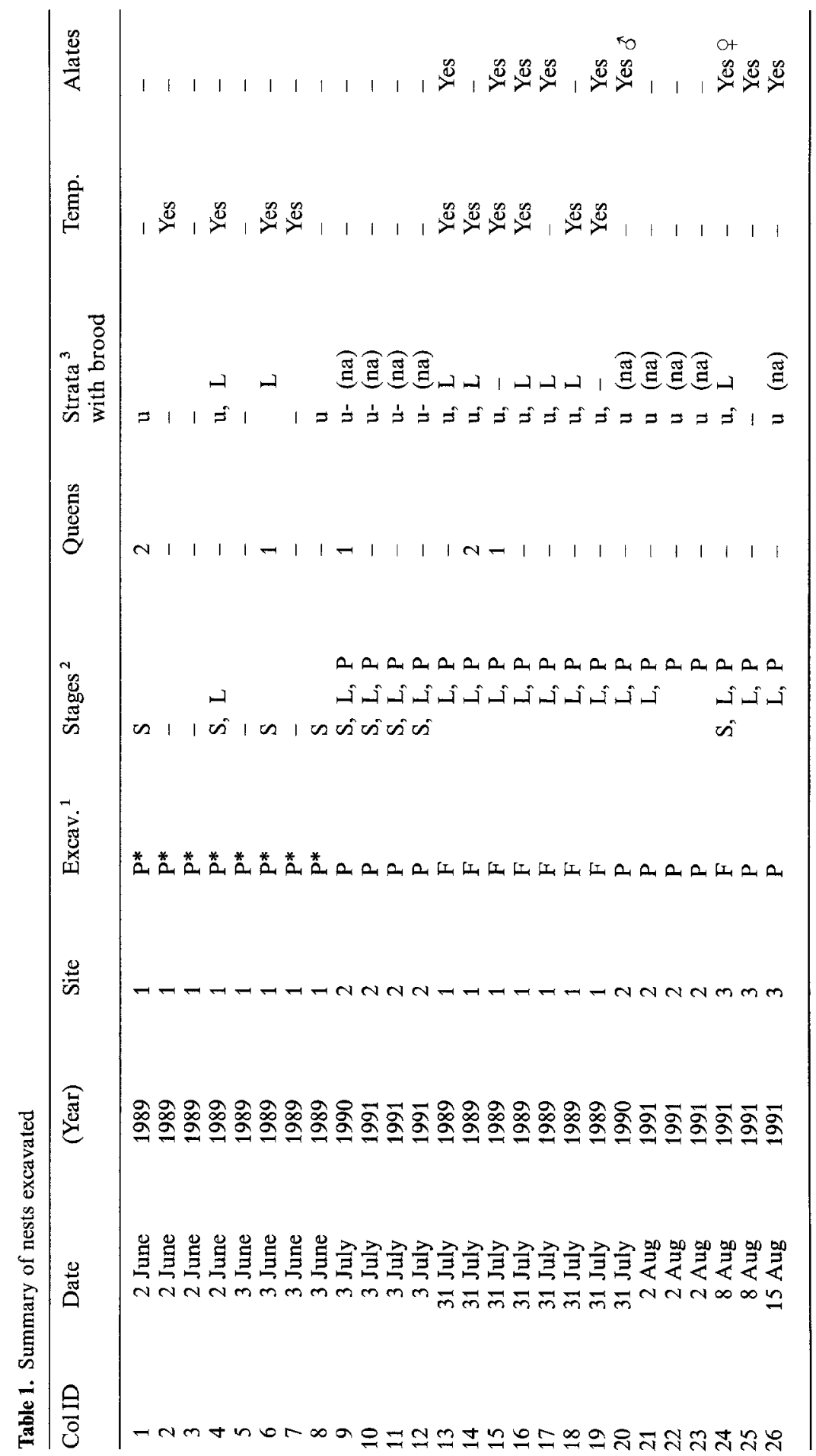




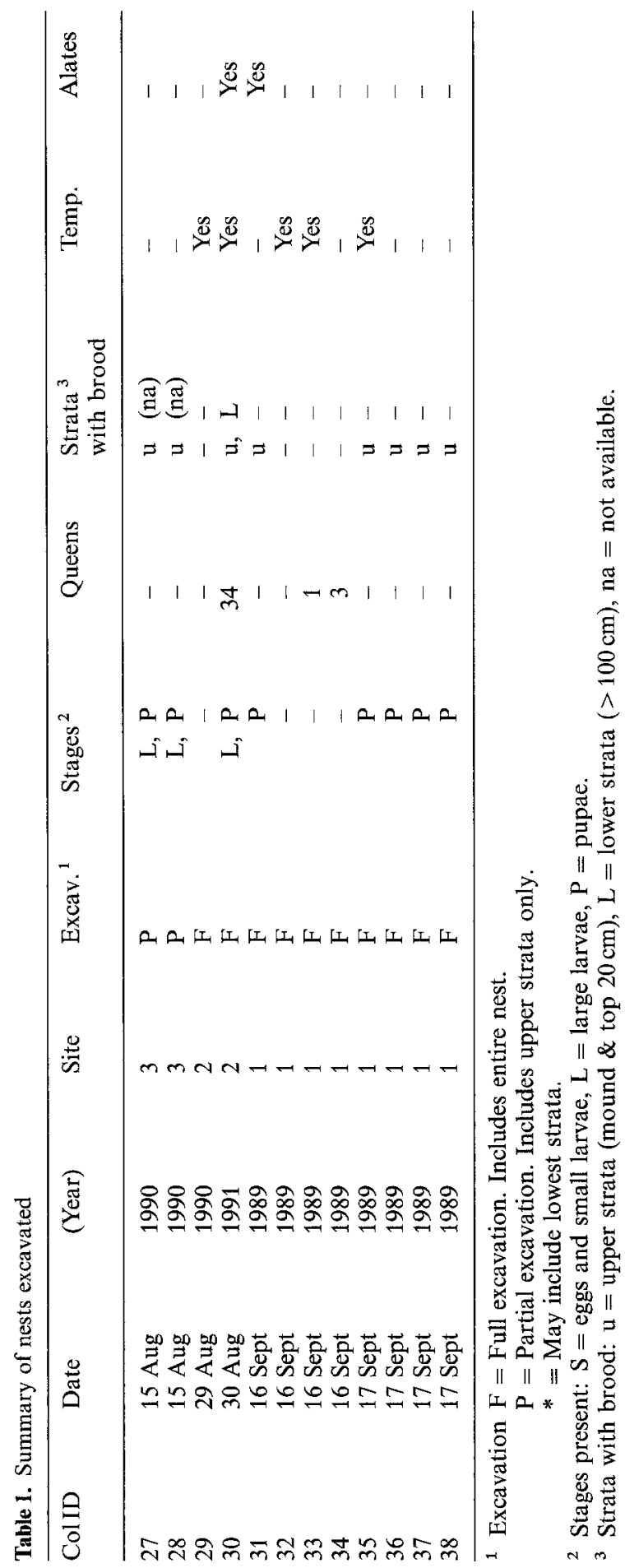


excavated in early, mid, or late season. The following criteria were used in selecting mounds: First, only medium-sized mounds were selected. No mound with a diameter of less than half a meter or more than three and a half meters was included. This limited the study to well-established nests. The upper limit was set for practical reasons of excavation, and excluded fewer than 10 percent of the mounds. Second, to avoid confounding effects of sampling more than one fragment of the same nest, sample mounds were at least $15 \mathrm{~m}$ from any other sample mound. Finally, all sample mounds showed significant ant activity when initially selected. This was stipulated to avoid selecting "dead" mounds. Even so, one mound had no activity when it was actually excavated in late July. Similar criteria were used in selecting study nests for further observations in 1990 and 1991.

To assess seasonal changes in brood and nest characteristics, eight mounds were sampled in each of the following three periods: Early season: June 3-4, 1989 (nests 1 8); Mid season: July 31 -August 1, 1989 (nests 13-19); Late season: September 1617 (nests 31-38). External measurements of height of mound from apex to soil surface and diameter of mound were taken. Diameter was taken as the mean of measurements along the $\mathrm{N}-\mathrm{S}$ axis and the $\mathrm{E}-\mathrm{W}$ axis. The following excavation technique was employed. One half of each mound was completely excavated to determine the volume of occupied soil and the quantity and stages of brood present. Soil was initially removed from the mound, and subsequently dug away in 20-cm layers to the bottom of the nest. Each sample consisted of one shovelful of soil containing approximately 2.91 (volume). Each sample was spread on a sheet of plywood and examined for 5 seconds, and the presence or absence of brood was scored. Since two to three samples could be processed simultaneously by different members of the field crew, this method allowed data to be recorded as rapidly as the nest was excavated. Samples with brood or reproductives were classified using the following categories: 1 . Small larvae/eggs - included first and second instar larvae as well as eggs. All three stages adhered in clumps, and were carried as clumps by workers. 2. Large larvae included third and fourth instar larvae which could be identified as individuals in the field, and which were carried individually by workers. 3. Pupae. 4. Alate reproductives or matured sexual brood. In addition, the number and location of dealate queens (potential colony reproductives) was recorded. Depth of measurement in the soil column references the soil surface rather than the mound apex. Excavations took between 90 minutes and two hours to complete for all but the deepest nests.

Excavation was continued until all soil containing galleries had been examined. The volume of the mound was estimated by calculating the volume of conical and cylindrical shapes approximating the excavated space. Soil temperature was determined during the excavation at 5, 30,60 and $90 \mathrm{~cm}$ depths for three to five nests per sample date. Galleries and openings were counted for one representative nest (No. 37) on the final date. Two $30 \times 30 \mathrm{~cm}$ square sections of the exposed nest were counted and sketched for the mound sector and each of the four depths stipulated above.

In addition to the primary sampling, observations were made on nest condition for several nests excavated for other purposes in mid-March, mid-June and October, 1989. In the later June excavations, we noted some galleries and ant activity at significantly greater depths than in our initial excavations. Consequently, we believe 
that the early June excavations may underestimate nest depth and volume, and we have excluded them from analyses on these variables. Except where otherwise specified, statistical comparisons are confined to the 24 nests sampled at Site 1 in 1989.

We attempted to address the question of whether workers carry brood to the bottom of nests when disturbed by conducting a very rapid excavation (nest No. 30) of a large nest on August 30,1991. The entire mound was cleared away in less than three minutes, and moved to a distance of several meters. Soil temperatures were taken during the excavation of the nest at $20 \mathrm{~cm}$ intervals for comparison with other soil temperature profiles.

Supplementary observations on brood presence, location and developmental stage were taken as follows: In 1990, mounds were excavated on July 2-4 (No. 9), July 31 (No. 20), and August 13-15 (No. 26-28). In 1991, partial excavations were conducted on each of three dates, July 3 (Nos. 10-12) and August 2 (Nos. 21-23). On each date, three mounds in or near Site 2 were excavated to depths of one-half to one meter, sufficient to allow the collection of 1200 workers, 500 larvae and 200 to 300 pupae per nest. On August 8, 1991, two additional nests (Nos. 24-25) were excavated from Site 3 .

\section{Nest dispersion}

Detailed maps and external measurements of all colonies in a $50 \mathrm{~m} \times 75 \mathrm{~m}$ quadrat area in Site 2 were made to assess mound density and dispersion. Analysis of nest dispersion was made using Clark and Evans (1954) nearest-neighbor index, R, to test for over- or underdispersion. $\mathrm{R}$ can vary from 0 (perfect aggregation) to 2.1491 (perfect hexagonal overdispersion), with a value of 1.0 indicating a random dispersion pattern. Nearest-neighbor distances were calculated to the true nearest neighbor mound regardless of whether it fell inside the quadrat boundaries, thus eliminating the confounding bias toward overdispersion that arises from sampling within a rectangular quadrat (Sinclair, 1985; Cushman et al., 1988). Significance was tested using a $\mathrm{z}$ transformation (Levings and Traniello, 1981). Analysis of variance was employed to test for seasonal differences in nest dimensions, possibly arising from mound-building activities of the ants during the season. Early-season nests were excluded from depth and volume analyses because of potential underestimates in these measures. Nest diameters for samples from Site 1 (1989) were compared with samples from Site 2 (1990) using an unpaired two-tailed t test. Correlation coefficients were computed to test for a relationship between nest depth and surface measurements, and for a relationship between nest size and the production of sexual forms.

\section{Soil temperature and moisture}

To compare specific conditions of soil moisture and temperature between actual nest conditions and unworked soil, a pair of excavations were conducted in parallel on a mound of intermediate size (No. 29) and an adjacent column of soil $5 \mathrm{~m}$ from the 
excavated colony. Both excavations were conducted at the same time and approximate speed. The excavated mound measured $145 \mathrm{~cm}$ diameter (N/S axis) by $160 \mathrm{~cm}$ (E/W axis) with a height of $41 \mathrm{~cm}$. The soil column excavated was approximately $150 \mathrm{~cm}$ in diameter. During the excavation process, soil temperatures and samples were taken at the mound apex, midway into the mound (approximately $20 \mathrm{~cm}$ above the soil surface), and at $20 \mathrm{~cm}$ intervals from the soil surface to a depth of $200 \mathrm{~cm}$. For all depths except the mound apex, soil temperatures were recorded for both the center of the nest and the edge of the nest. Two samples of soil (approximately $500 \mathrm{~g} / \mathrm{sample}$ ) were taken from each depth, sealed in airtight bags, and returned to the laboratory for drying and weighing. Similar samples and measurements were taken simultaneously on the soil column. Ambient air temperature (shade) and relative humidity were recorded simultaneously for comparison with temperatures recorded for each depth. Soil moisture was determined gravimetrically, by weighing out approximately $100 \mathrm{~g}$ of soil and drying it at $95^{\circ} \mathrm{C}$ until the sample weight stabilized (approximately 24 hours). Several soil samples were damaged in transit, so no measurements were available for the ant nest from $100 \mathrm{~cm}$ to $160 \mathrm{~cm}$; however no ants or galleries were observed below $100 \mathrm{~cm}$ in this colony.

\section{Results}

\section{Mound density and distribution}

No specific density or distribution data were collected at the primary site. In selecting sample nests, however, we observed that all the nests fell within a $10 \mathrm{~m}$ radius from one or more neighboring nests, and did not appear to be either clumped or overdispersed. The map of mounds at the second site confirmed our observation of an approximately random dispersion. Twenty six mounds were mapped within a $50 \mathrm{~m} \times 75 \mathrm{~m}$ quadrat area, yielding an overall density of about 7 mounds per $1000 \mathrm{~m}^{2}$. The mean nearest-neighbor distance was $5.83 \mathrm{~m}( \pm 3.8$ S.D.). The $\mathrm{R}$ value for Site 2 was 1.061 , which does not significantly depart from the expected value of 1.0 , indicating a random spatial distribution of nests.

\section{Dimensions of Mounds}

Table 2 summarizes the dimensions of ant mounds at the primary study site. There were no significant difference in nest dimensions between dates. (Mound height: $\mathrm{F}=2.49, \mathrm{p}>0.05, \mathrm{df}=2$. Mound diameter: $\mathrm{F}=0.47, \mathrm{p}>0.05, \mathrm{df}=2$. Mound depth: $F=0.39, p>0.05, \mathrm{df}=1$ (excluding early-season excavations). Mound volume: $\mathrm{F}=1.05, \mathrm{p}>0.05, \mathrm{df}=1$ (excluding early-season excavations)). Only weak correlations were found between above-ground measures of mound height and diameter with nest depth. $\mathrm{r}^{2}$ for height vs. depth was $0.001, \mathrm{p}>0.05 . \mathrm{r}^{2}$ for diameter vs. depth was $0.123, \mathrm{p}>0.05$.

The mean (average of $\mathrm{N} / \mathrm{S}$ and $\mathrm{E} / \mathrm{W}$ ) diameters of the 24 mounds sampled at Site 1 in 1989 were compared with the mean diameters of the 26 mounds mapped in the 
Table 2. Dimensions of nests of $F$. exsectoides

\begin{tabular}{llllll}
\hline Date & $\begin{array}{l}\text { Mounds } \\
\text { sampled }\end{array}$ & $\begin{array}{l}\text { Height } \\
\text { of mound } \\
(\mathrm{cm})( \pm 1 \text { S.D. })\end{array}$ & $\begin{array}{l}\text { Diameter } \\
\text { of mound } \\
(\mathrm{cm})\end{array}$ & $\begin{array}{l}\text { Depth of } \\
\text { galleries } \\
(\mathrm{cm})\end{array}$ & $\begin{array}{l}\text { Estimated } \\
\text { volume } \\
(\mathrm{m} 3)\end{array}$ \\
\hline June 3 & 8 & 30.9 & 258.1 & $58.8^{*}$ & $4.34^{*}$ \\
& & $( \pm 9.5)$ & $( \pm 95.7)$ & $( \pm 42.1)$ & $( \pm 2.55)$ \\
July 31 & 7 & 35.7 & 224.3 & 162.1 & 8.13 \\
& & $( \pm 7.3)$ & $( \pm 55.0)$ & $( \pm 30.0)$ & $( \pm 4.37)$ \\
Sept 16 & 8 & 38.9 & 231.9 & 170.6 & 6.01 \\
& & $( \pm 3.5)$ & $( \pm 54.9)$ & $( \pm 69.7)$ & $( \pm 2.10)$ \\
\hline
\end{tabular}

* Nest depth and volume estimates may reflect underestimates for the first sample period.

quadrat at Site 2 in 1990. The Site 1 mounds ranged from 60 to $340 \mathrm{~cm}$ in diameter (mean $=235.4 \pm 70.2 \mathrm{SD}$ ). In Site 2 , all mounds were mapped. The range of these 26 mounds was from 76 to $488 \mathrm{~cm}$ in diameter (mean $=215.1 \pm 106.8 \mathrm{~cm}$ ). These means were not significantly different $(\mathrm{t}=0.787, \mathrm{df}=48, \mathrm{p}>0.05$, unpaired $\mathrm{t}$ test $)$ in spite of the more restrictive criteria initially used in mound selection.

\section{Physical structure and characteristics of nests}

The distribution of galleries and tunnels by depth is illustrated in Fig. $1 \mathrm{~A}$, and the seasonal temperature profile of the nests excavated in 1989 is shown in Fig. 1 B. Galleries and tunneling were most extensively developed in the mound and upper $30 \mathrm{~cm}$ of the nest, falling off rapidly with increasing depth. Few galleries were observed below $90 \mathrm{~cm}$; however, some ants and activity were observed below $150 \mathrm{~cm}$ in 10 of the 15 mounds excavated in mid-and late season.

Soil temperature was influenced by both season and depth (Fig. 1 B). A two-way analysis of variance on temperature changes by date and depth indicates a significant difference due to both variables as well as a significant interaction (season, $\mathrm{F}=7.077$, $\mathrm{df}=2, \mathrm{p}<0.01 ;$ depth, $\mathrm{F}=8.078, \mathrm{df}=3, \mathrm{p}<0.001$; interaction, $\mathrm{F}=2.369$, $\mathrm{df}=6$, $p<0.05$ ). The top soil levels showed the greatest variation, being warmest in midseason and coolest in late season. By contrast, the deepest soil levels were least variable. The deepest nest (No. 33) was excavated to $300 \mathrm{~cm}$ below soil level on September 17. At 90 and $120 \mathrm{~cm}$, the temperature of this nest was $14^{\circ} \mathrm{C}$, and between 200 and $240 \mathrm{~cm}$ had dropped to only $13{ }^{\circ} \mathrm{C}$. Although deep levels remained relatively constant in temperature, overall the soil column warmed up about $5^{\circ} \mathrm{C}$ over the season.

Table 3 presents the specific details of air and soil temperatures and moisture for comparison of a single nest (No. 29) and adjacent soil column excavated on August 29,1991 . The pattern was broadly similar for this nest compared with the 24 nests excavated from Site 1 (Fig. 1 B). The mound was considerably warmer than the adjacent soil surface, closely tracking ambient temperatures. Initially, the temperature declined rapidly with depth to about $40 \mathrm{~cm}$, then continued to decline gradually to a constant temperature of approximately $14^{\circ} \mathrm{C}$ below $100 \mathrm{~cm}$. Soil moisture varied 
A. Gallery density and distribution

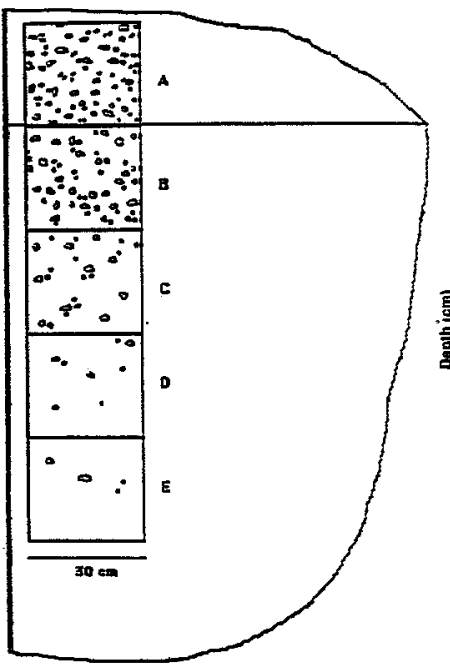

B.

Temperature proflle

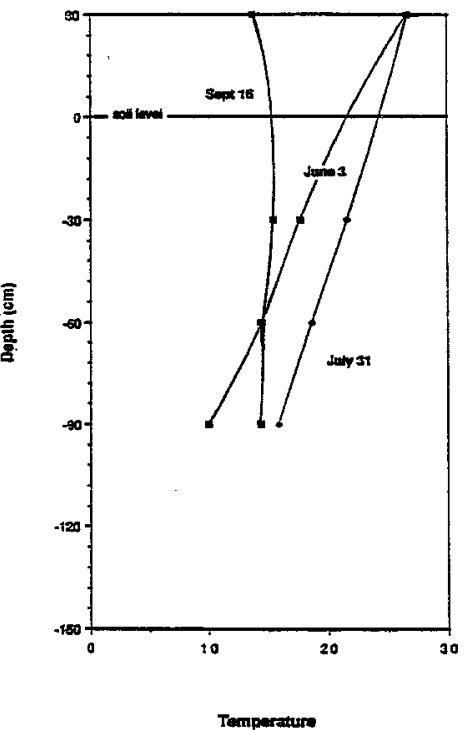

Figure $1 \mathrm{a}$. Density of gallery and tunnel openings from mound center to $120 \mathrm{~cm}$. Number of galleries based on average of counts of two $30 \mathrm{~cm} \times 30 \mathrm{~cm}$ cross sections at each depth from a representative mound (No. 18) excavated on September 16, 1989

Figure 1 b. Seasonal temperature profiles of $F$. exsectoides nests. Based on mean values of 5 nests (June 3), 4 nests (July 31) and 3 nests (September 16)

from about $3.0 \%$ to $4.0 \%$, except for the upper mound material which was very dry. In general, the nest soil was slightly warmer and slightly drier than the unworked adjacent soil; however, these differences were not significant (paired t test: soil temperature $-\mathrm{t}=-2.152, \mathrm{p}>0.05$; soil moisture $-\mathrm{t}=-2.313, \mathrm{p}>0.05)$.

\section{Seasonal presence and distribution of brood}

Preliminary digs conducted in March and April of 1988 and 1989 vielded only workers and queens from primarily depths between one and two meters; no brood stages or pupae were found during this period. The seasonal and within-nest distributions of brood during the active season are shown in Fig. 2. In the early season excavations, four of the eight nests had early stages of brood, and one nest additionally had late instar larvae. Midseason excavations revealed late brood and pupae, but no eggs or early larvae in any of the seven nests. By mid-September, the only brood stage encountered was pupae. Five of the eight nests excavated had some pupae, although the overall density was much lower than the mid-season sample. In 1991, one nest yielded small larvae on August 8, indicating that not all nests had finished producing brood by midseason. 


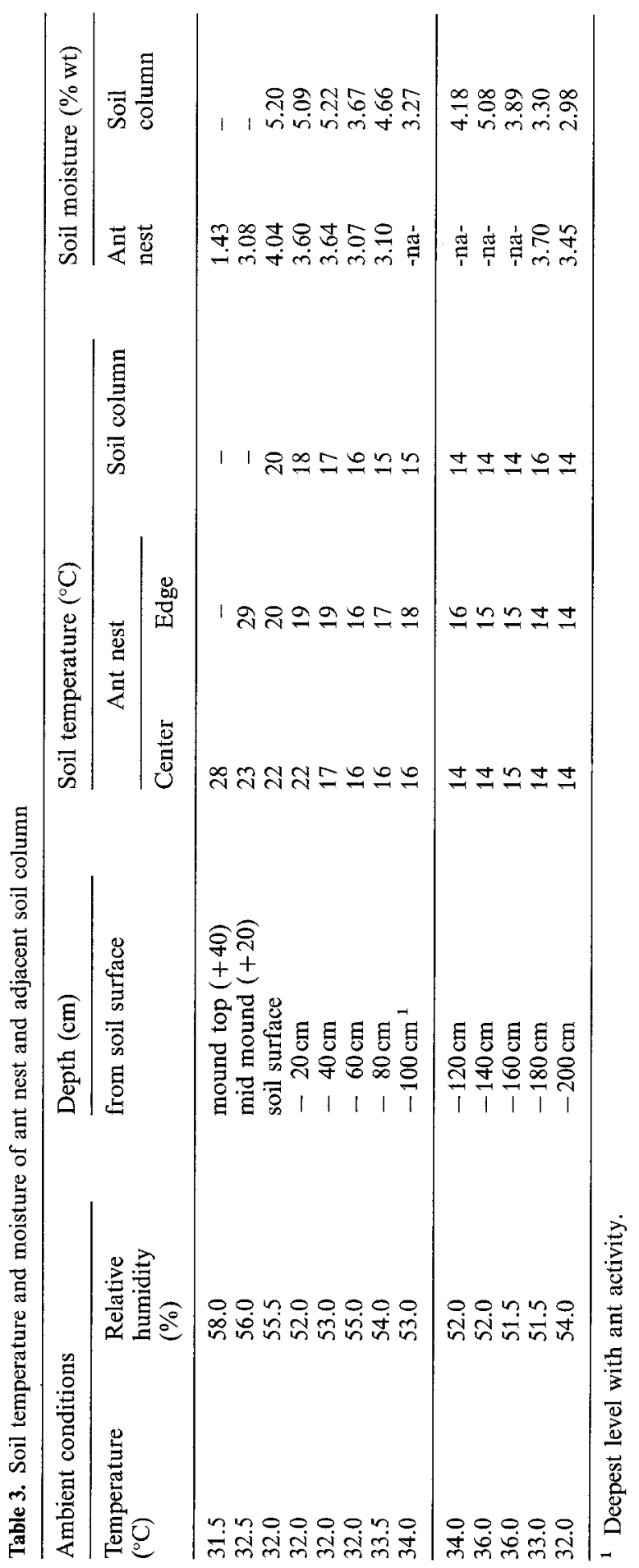



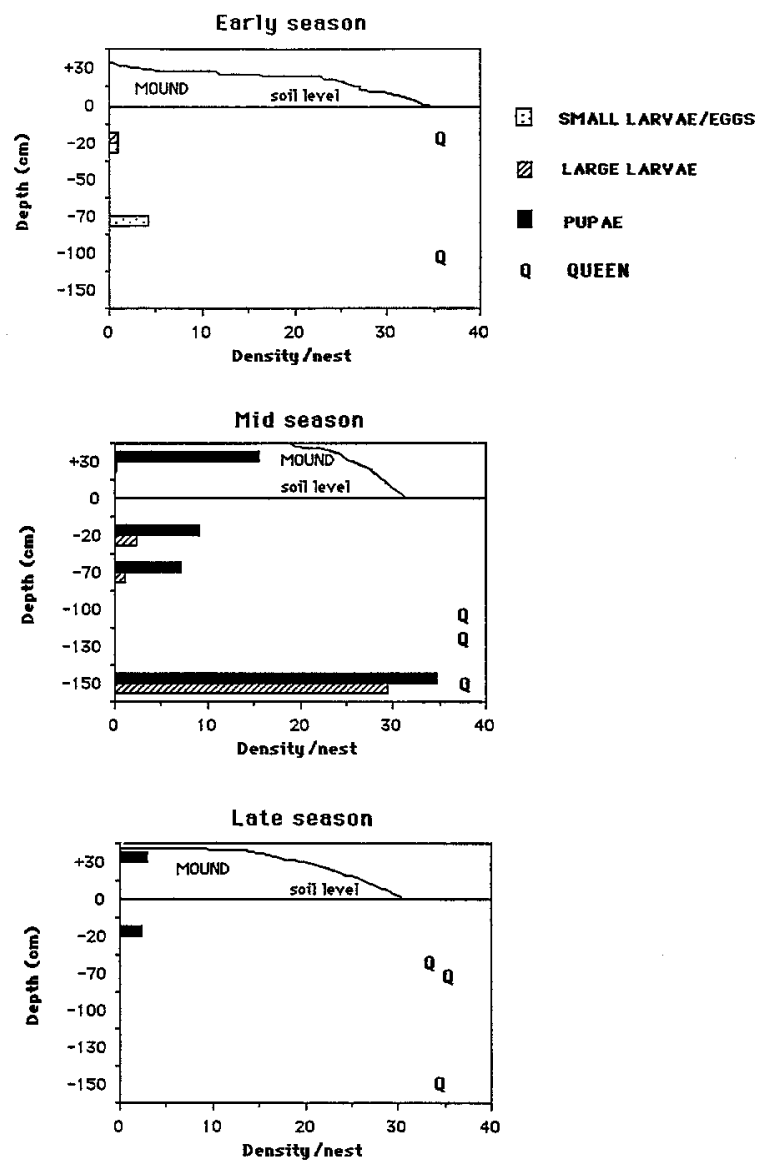

Figure 2. Seasonal presence and distribution of brood stages within nests. Density per nest indicates the number of samples (shovelfuls of soil) containing that stage recorded from the half-nest excavated. Bars represent averages for all nests excavated per date. Depths of functional queens denoted by symbol Q. Early season -8 nests excavated June 2-3; mid-season -7 nests excavated July 31 -August 1; late-season - 8 nests excavated September 15-16

The spatial distribution of brood stages varied within the nests. Early in the season, most brood were located in the upper half of the nest, but not in the mound itself. The midseason excavations revealed a bimodal stratification of late brood and pupae. Fifty-two percent of the samples containing pupae and 89 percent of the samples containing larvae were found at depths of at least $150 \mathrm{~cm}$, corresponding to the coolest portion of the soil profile. No brood of any stages were located between 70 and $150 \mathrm{~cm}$. An examination of the mound portion of the seven excavated nests revealed only a single sample with larvae present; however, 23 percent of the samples containing pupae were found in the mound. In late season, only a few pupal forms were excavated, all in the upper portion of the nest or in the mound.

On August 8, 1991, two nests (Nos. 24-25) were excavated in Site 3 to obtain brood and (for nest No. 24) information on the distribution of stages. The same 
Within-nest distribution of sexual forms
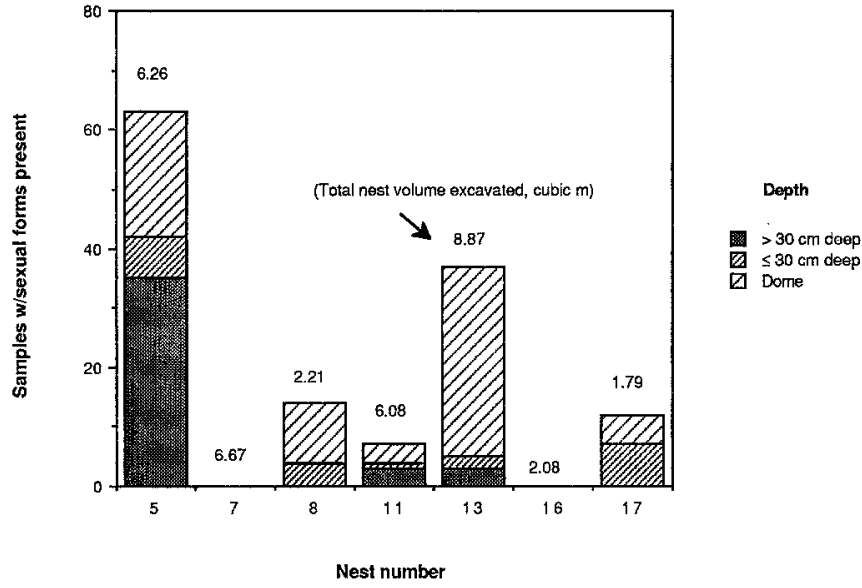

Figure 3. Mid-season presence and vertical distribution of alate reproductives within nests. Height of bars indicate number of samples (shovelfuls of soil) containing alate ants for the five nests excavated on July 31 and August 1 which contained sexual forms.

general pattern observed at Site 1 in 1989 was seen. The mound contained a large number of alate forms, all females. One brood pocket, which contained 60 large larvae and 19 small larvae, was excavated in the mound proper. No further brood were found above $80 \mathrm{~cm}$ depth. Five large larvae and several pupae were found together at about $90 \mathrm{~cm}$, and two more brood pockets were located; one at $120 \mathrm{~cm}$ contained 17 small larvae and 20 large larvae, the second at about $140 \mathrm{~cm}$ depth contained 12 small and 74 large larvae. Data from the rapid excavation of the large mound (No. 30) on August 30 resembled the pattern found in the late-season excavations of 1989. Most of the brood were in pupal form, and were found in the mound itself or in the upper $20 \mathrm{~cm}$ of soil. A few large larvae were recovered from a side gallery at about $150 \mathrm{~cm}$ depth.

\section{Seasonal presence and distribution of sexual forms}

Alate sexual forms were produced by five of the seven nests excavated in 1989 (Fig. 3). The number of reproductives did not appear to be correlated with the size of the nest (nest volume vs. samples with reproductive forms: $\mathrm{r}^{2}=0.197 ; \mathrm{p}>0.05$ ). In most nests, the alate forms were found predominantly in the mounds or upper nest strata. One exception, mound No. 13, yielded 35 samples with winged forms from the deeper layers. By late season, almost all the alate forms were gone. One late-season nest (No. 31) contained two samples with alates from the mound region, but no other winged ants were observed during this period.

No flight activity or mating was recorded; however, alate queens were observed in 1991 on low foliage on July 31 at Site 2 and on August 1 at Site 3. These queens both exhibited the same behavior: they repeatedly ran up and back along a pine branch, at 
a height of 1 to $2 \mathrm{~m}$, drumming their abdomens on the branch surface. In each case, this behavior was observed for about 5 minutes; no males were seen.

Dealate queens were recovered from six of 24 nests in 1989, however, three of these nests contained multiple queens. Details of spatial distribution of queens within nests are shown in Fig. 2. Queens collected in early- and mid-season 1989 continued laying eggs in the laboratory, and thus were considered to be functional reproductives. Late season queens produced eggs the following spring. In 1991, the rapid excavation of the large nest (No. 30) on August 30 yielded 34 dealate queens. Twentyfive of these were found in the top $20 \mathrm{~cm}$ of soil in side galleries extending beyond the boundaries of the mound itself. Dissections of several of these queens revealed large fat bodies and relatively undeveloped ovaries with no signs of follicular relict or yellow bodies. This physiological condition paralleled that of alate unmated females collected from the parent nests in late July.

\section{Discussion}

The Allegheny mound ant, F. exsectoides, forms a striking component of the arthropod fauna of the habitats it dominates. Hölldobler and Wilson (1990) describe it as a typical example of a unicolonial species - a social species which exhibits no colony boundaries. This behavior, which is tied to the ants' habits of polygyny, polydomy and treating all conspecifics in the area as nestmates, allows the population to build up and behave as a single unit or supercolony. In the process of reaching the densities described by McCook (1877), Andrews (1925a) or described here, the ants may radically alter the community composition, by the reduction of other ant species (Hölldobler and Wilson, 1990), by predation on herbivorous arthropods (Campbell, 1990), or even by damage to vegetation (Peirson, 1922, 1923; Andrews 1928).

Mounds ranged from less than $60 \mathrm{~cm}$ in diameter to almost $500 \mathrm{~cm}$, although most were in the range of 150 to $300 \mathrm{~cm}$. These mounds were slightly larger than those in the population studied by Salem and Hole (1968), which averaged $110 \mathrm{~cm}$. The spatial distribution of $F$. exsectoides nests did not significantly differ from random.

The internal structure of the mound nests reported here confirms and expands on previous descriptions (McCook, 1877; Andrews 1925a, 1929a); however, the nest depth is considerably greater than previously recorded, and the density of galleries is greater at intermediate depths than other studies suggest. Temperature profiles of nests over the season are similar in shape to those reported elsewhere (Andrews, 1927). Surface temperatures vary with changes in the ambient temperature; however, by depths of 90 to $120 \mathrm{~cm}$, little variation in temperature occurs. This differs from other well-studied mound-building species, most of which are in the $F$. rufa group. For example, no large brood chambers such as those described for the western thatching ant Formica obscuripes Forel (McCahon and Lockwood, 1990) were observed at any level. The related European species $F$. polyctena has a heat center in the mid-regions of the nest, generated by decaying nest materials and the metabolic heat of the ants themselves (Coenen-Stass et al., 1980; Coenen-Stass, 1988). By comparison, F. exsectoides, a member of the $F$. exsecta group, shows no evidence of such a heat center in its mounds. Consequently, with the exception of the dome, there 
is little difference in either the temperature or moisture profiles of Allegheny mound ants' nests compared with unoccupied soil.

Numerous authors have suggested that a primary function of the dome is microclimate regulation (Huber, 1810; Andrews, 1927; Scherba, 1962). Our findings support the idea that the mound may provide an area of warmer temperatures and lower humidity than the remainder of the nest. However, the spatial arrangement of brood at different layers of the nest departs from patterns observed for most moundbuilding species which keep their immature stages in or near the mound. We observe, in fact, that most of the brood, at least during periods of peak brood production, are found in the lowest strata of the nest. There are several possible explanations for this pattern; firstly, it may reflect a defense response on the part of workers to carry brood to the safest regions of the nest when it is disrupted. Secondly, it may reflect the fact that the deepest strata represent the most favorable microclimate for brood in the overdrained soils favored by this species, since ants are known to relocate brood into regions of temperature and humidity which are optimal for each stage (Ceusters, 1977). Finally, it may serve as an adaptive function in the colony cycle of the ants, allowing synchrony of brood development through regulated thermal accumulation, thus providing a mechanism for finetuned regulation of recruitment into the worker pool.

We are unable to rule out the possibility that the observed pattern reflects an artifact of the excavation itself. Our rapid excavation uncovered some pupae in the mound, and only a few larvae at depth. This pattern is consistent with the hypothesis that bimodal brood distribution is an artifact of excavation; however, it can also be explained as the normal pattern we would expect late in the season (see Fig. 2, late season). Further work will be needed to rule out the artifact hypothesis; however, some observations lend support to the hypothesis that the described distribution of brood reflects the true spatial patterns of nest use. Firstly, brood tend to be found highly aggregated in discrete pockets. This was equally true for brood in the bottom strata and in the top strata. Additionally, no such pockets were located in intermediate depths, and virtually no individual brood were observed in these regions. If ants were carrying brood to the safety of the deep parts of the nest, we would predict that brood distribution would be more diffuse at these depths, since workers would lack time to aggregate all the brood into one or two pockets. We would additionally predict that we would find more individual larvae at intermediate depths, and that we would occasionally find workers in transit with brood through these depths. Finally, we would predict that we would also observe queens in these lower levels. No such observations were recorded.

The alternative explanation is that the ants selectively keep much of their brood in the deeper nest strata. Hölldobler and Wilson (1990) report that most ants keep their brood in the warmest chambers, with eggs and larvae kept in areas of high humidity while pupae are placed in drier portions of the nest. Our observations of the spatial distribution of brood of $F$. exsectoides departs from this pattern, with substantial proportions of both larvae and pupae being found in the cooler deeper parts of the nest, while a small fraction are moved to the upper warmer regions. The extremely dry nature of the soils used by $F$. exsectoides may place a premium on humidity control rather than temperature per se. Laboratory colonies have shown a particular 
Formica exsectoides: Annual colony cycle

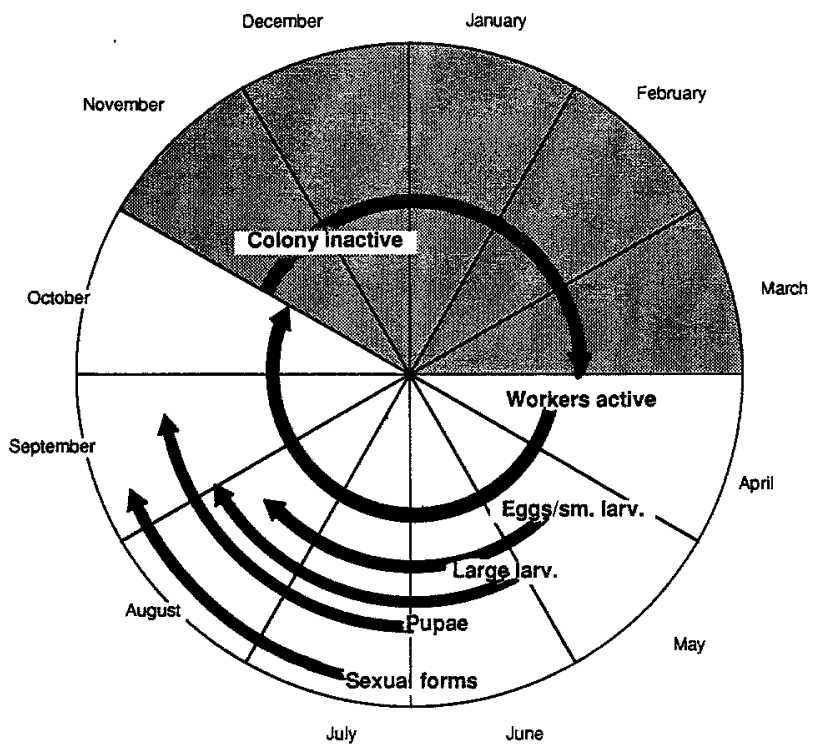

Figure 4. Annual colony cycle for Formica exsectoides F. in central Michigan

sensitivity to humidity, consistently preferring moist or saturated areas for larval chambers (Bristow, unpub. data). Although absolute moisture levels are more or less equal through the soil column, the deeper cooler regions where most larvae are found will have a higher relative humidity and may be less prone to water loss through evaporation. Further studies are needed to test the role of moisture.

A third explanation for the observed pattern may reflect a novel homeostatic mechanism that could allow ants to exercise some control over the rate of larval development by moving them from warm to cool regions and back. Wilson and Hölldobler (1988) have documented other types of complex biofeedback mechanisms which allow colonies to synchronize brood development with demands for new foragers. Depths where we regularly encountered larvae were consistently and predictably cool. Larval development could be deliberately slowed by moving brood into this area, or speeded up by moving brood into the mound region. This could provide a mechanism that would allow synchronization of some stages, such as alate forms, or selective and rapid recruitment of new workers to rapidly changing external conditions. Although some ant species that inhabit hot climates construct brood chambers in deeper soil strata (Tschinkel, 1987), mound-building ants of northern temperate forests are thought to use the upper nest regions and mound as brood incubators (Coenen-Stass et al., 1980). The departure of $F$. exsectoides from the more typical pattern of European species merits further attention.

The general colony cycle of $F$. exsectoides in central Michigan is summarized in Fig. 4. The overwintering nest consists of workers and queens but no brood. Ants are 
torpid from the onset of cold weather, and can be collected in aggregations at depths of a meter or more during the winter and early spring. Workers can be observed at the surface of the mound with the advent of warmer weather, and have been reported to become active following several warm days in winter (Dimmick, 1951). By the beginning of June, half of the sampled colonies had begun to produce eggs, and a few late instar larvae had matured. The peak brood population is estimated to occur in mid-July.

Formica exsectoides has been described as polygynous; however, there is considerable variation in the reported number of queens per mound. Andrews (1929b) counted 10 queens in one nest, while Cory and Haviland (1938) reported 40 queens from one mound and 1407 queens from a second. Our excavations confirmed the presence of multiple functional queens in several nests; however, the largest number of functional queens excavated from any nest was three. The rapid excavation on August 30,1991 revealed that a large number of potential queens can be found in the peripheral galleries. Since dissections of these females indicated that they had not oviposited, we believe that they represent potential or supernumerary reproductives from the mating activity of the previous month. It is not known to what degree they are successful at being adopted back into the colony. However, some work on the genetic structure of this species (Nipson, 1978) indicates a significant degree of genetic variation within nests.

Sexual brood was produced from early July to August. Not all nests produced reproductives every year. In our study, approximately one quarter of the nests produced no sexual forms. When reproductives were produced, one sex may predominate. Both the nests excavated on July 31, 1990 (No. 20) and August 8, 1991 (No. 24) had many alate forms, but the former all appeared to be males while the latter only contained females. This investment on a nest-by-nest basis in production of one or the other sex has been documented for other species (Nonacs, 1986a, b) and has been linked with variation in resource availability (Rosengren and Pamilo, 1986). In most nests, alate forms were located in the mound and upper few centimeters of soil. However, in one nest (No. 13), hundreds of males were collected below $20 \mathrm{~cm}$ in association with one alate female.

There is no indication of the presence of auxiliary or satellite nests for the production of sexual brood which are separated from the queen-bearing nests, as may be the case for some other Formica species. Firstly, all mounds tend to remain active from year to year, and have been recorded to be active in one site for up to 30 years (Andrews, 1926). Secondly, early spring excavations of randomly selected mounds generally yielded functional queens (pers. obs.), suggesting that all active mounds tend to have reproductives. Finally, our observations indicated that reproducing queens and rearing of sexual and non-sexual brood regularly occurred in the same nest. Nest No.15, for example, contained both a functional queen and alate reproductives. Other nests including Nos. 1, 6, 9, 14 and 15 contained functional queens and reproductive pupae.

The Allegheny mound ant has been described as "the most common mound building ant of North America" (Andrews, 1926). Where it occurs, it significantly modifies the landscape, including the distribution of vegetation and other arthropod species. Its voracious predaceous activities make it a potentially important biological 
control agent throughout its range. In this report, we present details of the life history of this species which may be useful in developing management programs that utilize its unique properties. This is of particular interest, since many of the details of its life history and biology depart significantly from the better-studied European moundbuilding species.

\section{Acknowledgements}

We wish to thank Andre Francoeur for his identification of the ants. This work was partially supported by USDA Grant No. 91-37302-6190. The manuscript was improved by comments from three anonymous reviewers.

\section{References}

Andrews, E. A., 1925a. Growth of ant mounds. Psyche 32:75-87.

Andrews, E. A., 1925 b. McCook's ant mounds in Pennsylvania, revisited (Hymen: Formicidae). Ent. News 36:173-179.

Andrews, E. A., 1926. Sequential distribution of Formica exsectoides Forel. Psyche 33:127-150.

Andrews, E. A., 1927. Ant mounds as to temperature and sunshine. J. Morph. Physiol. 44:1-20.

Andrews, E. A., 1928. Injuries to vegetation by mound-building ants. Am. Nat. 62:63-75.

Andrews, E. A., 1929a. The strength of ant mounds. Am. Nat. 63:540-552.

Andrews, E. A., 1929 b. Populations of ant mounds. Q. Rev. Biol. 4:248-257.

Campbell, N. J., 1990. An evaluation of Formica exsectoides Forel as a potential biological control agent of insect pests of pines. Ph. D. dissertation. Michigan State University, publ. East Lansing.

Campbell, N. J., C. Bristow, G. Ayers and G. Simmons, 1991. Design and field test of portable colonies of the predaceous ant, Formica exsectoides (Hymenoptera: Formicidae). J. Kans. Entomol. Soc. 64:116-120.

Ceusters, R., 1977. Social homeostasis in colonies of Formica polyctena (Hym. Form): nestform and temperature preferences. pp 111-112 in Proc. 8th Congress, IUSSI, Wageningen.

Clark, P. J., and F. C. Evans, 1954. Distance to nearest neighbor as a measure of spatial relationships in populations. Ecology 35:445-453.

Coenen-Stass, D., 1988. Zum Wärmehaushalt im Nest der Roten Waldameise, Formica polyctena (Hymenoptera, Formicidae). Mitt. Dtsch. Ges. Allg. Angew. Ent. 6:140-145.

Coenen-Stass, D., B. Schaarschmidt and I. Lamprecht, 1980. Temperature distribution and calorimetric determination of heat production in the nest of the wood ant, Formica polyctena (Hymenoptera, Formicidae). Ecology 61:238-244.

Cory, E. N., and E. E. Haviland, 1938. Population studies of Formica exsectoides Forel. Ann. Entomol. Soc. Am. 31:50-57.

Creighton, W. S., 1950. The ants of North America. Bull. Museum Comp. Zool. Harvard 104:1-585.

Cushman, J. H., G. D. Martinsen and A. I. Mazeroll, 1988. Density- and size-dependent spacing of ant nests: evidence for intraspecific competition. Oecologia 77:522-525.

Dimmick, J. F., 1951. An ecological study of Formica exsectoides. Ill. Acad. Sci. Trans. 44:197-204.

Hölldobler, B., and E.O. Wilson, 1990. The Ants. The Belknap Press of Harvard Univ. Press. Cambridge, Mass. xii $+732 \mathrm{p}$.

Huber, P., 1810. Recherches sur les Moeurs des Fourmis Indigenes. J. J. Paschoud., Paris. xiii +328 p.

Levings, S. C., and J. F. A. Traniello, 1981. Territoriality, nest dispersion, and community structure in ants. Psyche $88: 265-319$.

MacDonald, N.W., 1983. The effects of simulated acid precipitation on regeneration and soils in the jack pine-Grayling and ecosystem. M. S. Thesis. Michigan State University. East Lansing, MI. 
McCahon, T.J., and J.A. Lockwood, 1990. Nest architecture and pedoturbation of Formica obscuripes Forel (Hymenoptera: Formicidae). Pan-Pacific Ent. 66:147-156.

McCook, H. C., 1877. Mound-making ants of the Alleghenies, their architecture and habits. Trans. Entomol. Soc. Am. 6:253-296.. plates 1-6.

Nipson, H. E., 1978. Inbreeding in the ant species Formica exsectoides. Ph. D. dissertation. Harvard University. Cambridge, Mass.

Nonacs, P., 1986a. Ant reproductive strategies and sex allocation theory. Q. Rev. Biol 61:1-21.

Nonacs, P., 1986 b. Sex-ratio determination within colonies of ants. Evol. 40:199-204.

Peirson, H. B., 1922. Mound building ants in forest plantations. J. Forest. 20:325-336.

Peirson, H. B., 1923. Insects attacking forest and shade trees. Bull. Maine For. Serv. 1:37-39.

Rosengren, R., and P. Pamilo, 1986. Sex ratio strategy as related to queen number, dispersal behaviour, and habitat quality in Formica ants (Hymenoptera: Formicidae). Ent. Generalis $11: 139-151$.

Salem, M.Z., and F. D. Hole, 1968. Ant (Formica exsectoides) pedoturbation in a forest soil. Soil Sci. Soc. Amer. Proc. 32:563-567.

Scherba, G., 1962. Mound temperatures of the ant Formica ulkei Emery. Amer. Midl. Naturalist. $67: 373-385$.

Sinclair, D. F., 1985. On tests of spatial randomness using mean nearest neighbor distance. Ecology $66: 1084-1085$.

Strommen, N.D., 1971. Climatological summaries for Mio, Houghton Lake, Higgins Lake, and Grayling, Michigan. Michigan Department of Agriculture. Michigan Weather Service.

Tschinkel, W. R., 1987. Seasonal life history and nest architecture of a winter-active ant, Prenolepis imparis. Ins. Soc. 34:143-164.

USDA, 1976. Grayling series soil description sheet. Revised 5/13/76. Soil Conservation Service. Lincoln, Neb.

Wheeler, W. M., 1910. Ants: Their Structure, Development and Behavior. Columbia Univ. Press, New York, $\mathrm{xxv}+663 \mathrm{p}$.

Wilson, E. O., and B. Hölldobler, 1988. Dense heterarchies and mass communication as the basis of organization in ant colonies. Trends in Ecol Evol. 3:65-68.

Received 11 June 1991;

revised 25 November 1991 and 30 April 1992;

accepted 8 May 1992. 